\title{
Ipsilateral lingual paresis due to pontine infarct
}

Figure Ipsilateral lingual paresis and contralateral facial paresis due to isolated pontine infarct
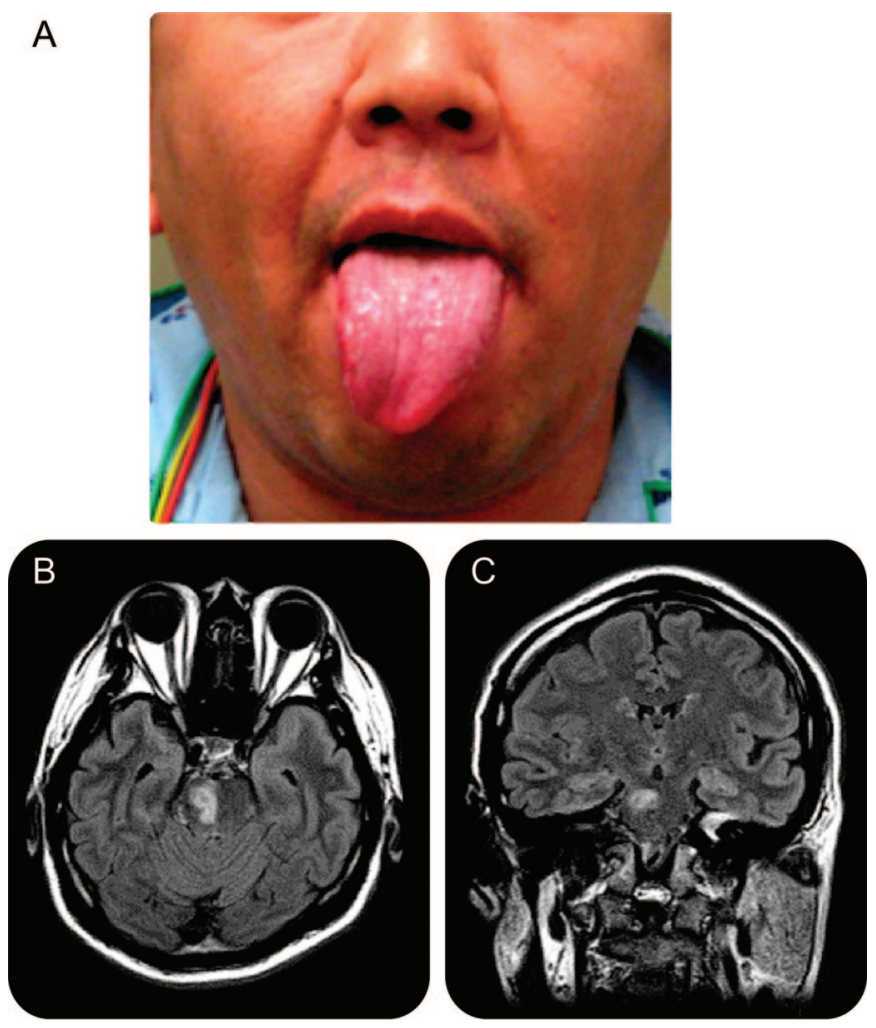

(A) Tongue shifted to the right side. The left nasolabial fold was shallow and the left corner of the mouth shifted downward. Axial (B) and coronal views $(C)$ of fluid-attenuated inversion recovery imaging showed a hyperintensity signal lesion in the right rostral pons.

A 47-year-old hypertensive man developed dysarthria suddenly. Examination revealed left hemiparesis and right hypoglossal nerve paresis without lingual atrophy or fasciculations (figure, A). A tongue EMG was normal. Brain MRI displayed an acute infarct in the right rostral pons (figure, B and C). The motor topography in the basis pontis is consistent with the rostral and medial localization of articulation. ${ }^{1}$ Corticohypoglossal projections usually cross at the pontomedullary junction whereas the uncrossed projections pass laterally in the basis pontis. ${ }^{2}$ Damage to those uncrossed fibers may cause ipsilateral supranuclear lingual paresis. The present radiologic findings support the possibility of aberrant cortico-hypoglossal projections.

T. Kiyozuka, MD, K. Ikeda, MD, PhD, T. Hirayama, MD, Y. Ishikawa, MD, J. Aoyagi, MD, Y. Iwasaki, MD, Tokyo, Japan

Disclosure: The authors report no disclosures.

Address correspondence and reprint requests to Dr. Ken Ikeda, Department of Neurology, Toho University Omori Medical Centre, 6-11-1, Omorinishi, Otaku,Tokyo 143-8541, Japan; keni@med.toho-u.ac.jp

1. Schmahmann JD, Ko R, MacMore J. The human basis pontis: motor syndromes and topographic organization. Brain 2004; 127:1269-1291.

2. Urban PP, Hopf HC, Connemann B, Hundemer HP, Koehler J. The course of cortico-hypoglossal projections in the human brainstem. Functional testing using transcranial magnetic stimulation. Brain 1966;119:1031-1038. 


\section{Neurology}

\section{Ipsilateral lingual paresis due to pontine infarct}

T. Kiyozuka, K. Ikeda, T. Hirayama, et al.

Neurology 2010;75;2038

DOI 10.1212/WNL.0b013e3181ff970f

This information is current as of November 29, 2010

\section{Updated Information \&} Services

References

Subspecialty Collections

Permissions \& Licensing

Reprints including high resolution figures, can be found at: http://n.neurology.org/content/75/22/2038.full

This article cites 2 articles, 0 of which you can access for free at: http://n.neurology.org/content/75/22/2038.full\#ref-list-1

This article, along with others on similar topics, appears in the following collection(s):

Clinical neurology examination

http://n.neurology.org/cgi/collection/clinical_neurology_examination

CME

http://n.neurology.org/cgi/collection/cme

Infarction

http://n.neurology.org/cgi/collection/infarction

MRI

http://n.neurology.org/cgi/collection/mri

Information about reproducing this article in parts (figures,tables) or in its entirety can be found online at:

http://www.neurology.org/about/about_the_journal\#permissions

Information about ordering reprints can be found online:

http://n.neurology.org/subscribers/advertise

Neurology ${ }^{\circledR}$ is the official journal of the American Academy of Neurology. Published continuously since 1951 , it is now a weekly with 48 issues per year. Copyright Copyright $@ 2010$ by AAN Enterprises, Inc.. All rights reserved. Print ISSN: 0028-3878. Online ISSN: 1526-632X.

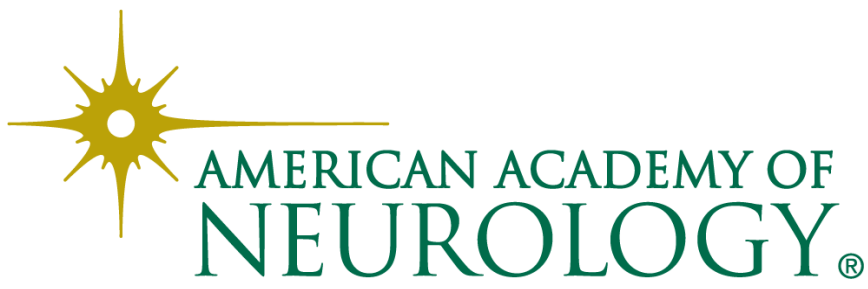

